\title{
Transcending National Borders in Nuruddin Farah's Maps
}

\section{* Dr. Mai Mohammad Abbas}

\begin{abstract}
Maps celebrates the coming of age of Askar Cali-Xamari, the Somali protagonist, who discovers his identity amidst the turmoil of the Ogaden war between Somalia and Ethiopia. Askar goes through three stages throughout the course of the novel. The first stage is the one in which Askar identifies himself with the woman world of Misra. In this stage, there exists the strikingly emotional and bodily closeness between Misra and Askar. Misra does not represent an Ethiopian figure; instead, she represents a multicultural figure. The second stage starts with Askar's circumcision, his ritual transference to the world of manhood. This stage represents a corporeal barrier between Askar and Misra. Askar is detached and weaned from his mother-figure Misra because he is able to find a substitute in Somalia, his mother country. In this stage, Askar is entrapped within the borders drawn on maps, not being aware that even maps can be manipulated by means of political and military agendas. The third stage includes Askar's journey to Mogadiscio. Askar's uncle, Hilal, refers to the fact that Ethiopia is generic because of its mélange of tribes, but Somalia is specific because of its common language. For Askar, this argument destroys the Somali claim to particularity. Askar becomes aware of the structured nature of borders. He is eventually able to adopt a multicultural identity.

Key Words: multiculturalism, virtual borders, political manipulation

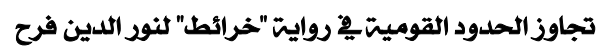

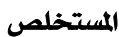

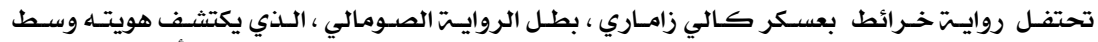

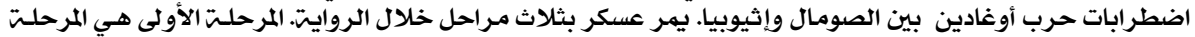

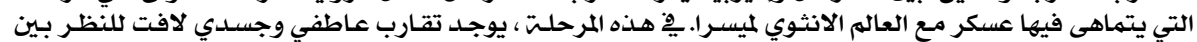

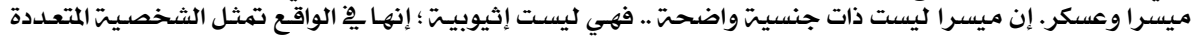

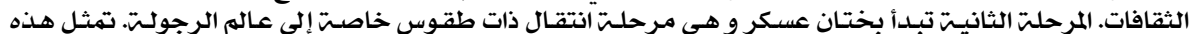

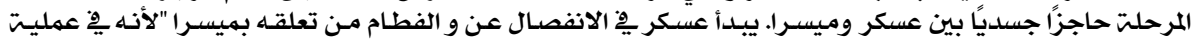

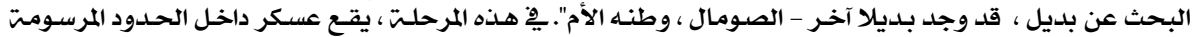

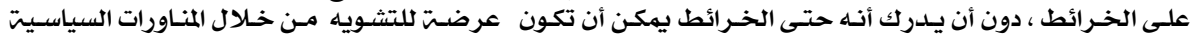

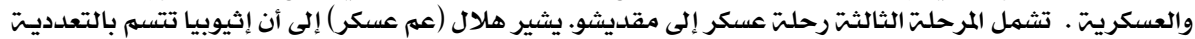

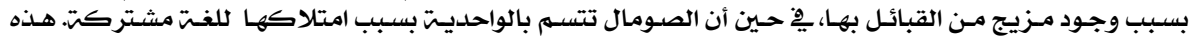

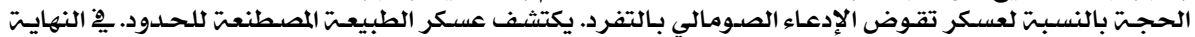
يستطيع عسكر ان يتبنى هويت متعددة الثقافات.

Keywords: national identity-radicalism-multiculturalism - ethnic inclusiveness pluralism-alienation -gender -free identity.
\end{abstract}

* Assistant Professor in the Department of English Language and Literature, Faculty of Arts, Tanta University. $\square$ 
But I am the exile.

Seal me with your eyes.

Take me wherever you are-

Take me whatever you are.

Restore to me the color of face

And the warmth of body

Mahmud Darweesh (as cited in Said, 2000, p. 179)

Nurruddin Farah is one of Africa's most celebrated novelists. Portraying the tyrannies of the African dictatorship ${ }^{1}$ in Somalia under the rule of Mohamed Siad Barre, Farah was forced into a self-imposed exile that lasted for twenty-two years. Despite leaving Somalia behind, Farah expresses how the terrible miseries of the war still reside within his psyche. He realizes that all these miseries start with the first bullet; this bullet brings the whole world to its knees:

Sadly, I hear the echo of the first shot and replay it very often in the ears of my recall. And I remember being overwhelmed with the oddest sensations, as if an insect began to crawl down my spine, towards the nether regions of my self-reprimand. . I I remember a most awkward sensation, as if the archangel of death had served his notice on me; as if I died a quick death, but just before doing so, was able to think ahead: and I saw corpses, hundreds, thousands of unburied bodies, and a million people fleeing a savaging crisis . . . I associate so much destruction with that single bullet, which keeps ringing in the ears of my memory. (Farah, 1996, pp. 114-115)

Farah writes Maps to overcome his painful experience of war and diaspora. Unlike other African novels like Ben Okri's The Famished Road ${ }^{2}$ which only concentrates on the agonies of war while affording no psychic or spiritual alternatives for such agonies, Farah, through a therapeutic emotional journey, manages to bring his own traumas and afflictions to resolution: a fluid rather than a dogmatic identity that is aware of the myth of physical or linguistic barriers. In his article, "Bastards of Empire: Writing and The Politics of Exile," Farah (1995) writes, "for various reasons, it seems appropriate to mention straightway that for a little 
under 20 years I've dwelled in the dubious details of a territory I refer to as the country of my imagination" (26). However, Farah eventually learns to demystify the static and imaginary forms of national identities. In "A Country in Exile" (1998), Farah says that he "felt joined more to [his] writing than to any country with a specific territoriality" (p. 4)

Within the same context, Hal foster argues for "a postmodernism of resistance" which can be deployed "to stress difference and marginality, valorizing the culture and practices of individuals and groups excluded from mainstream culture, generating a cultural studies of the margins and oppositional voices" (as cited in Kellner, 2001, p. 11). Foster underlines the post-modern culture's positive role in "the democratization of culture and [in] new individual and political possibilities" (as cited in Barker, 2004, p. 157). Like Foster, Stuart Hall (1992) sees the post-modern culture from a positive perspective, describing it as a form of "multiculturalism" that can encompass oppositional or marginal voices:

If the global postmodern represents an ambiguous opening to difference and to the margins and makes a certain kind of decentering of the Western narrative a likely possibility; it is matched, from the very heartland of cultural politics, by the backlash: the aggressive resistance to difference; the attempt to restore the canon of Western civilization; the assault, direct and indirect, on multiculturalism; the return to grand narratives of history, language, and literature (the three great supporting pillars of national identity and national culture). (p. 25)

Within this theoretical framework that condones multiculturalism and condemns the aggressive resistance of to difference, Farah's novel Maps celebrates the coming of age of Askar Cali-Xamari, the Somali protagonist, who discovers his identity amidst the turmoil of the Ogaden war $^{3}$ between Somalia and Ethiopia. Askar goes through three stages throughout the course of the novel. The first stage is the one in which Askar identifies himself with the woman world of Misra. In this stage, there exists the strikingly emotional and bodily closeness between Misra and Askar. Misra does not represent an Ethiopian figure; rather, she 
represents a multicultural figure. The second stage starts with Askar's circumcision, his ritual transference to the world of manhood. This stage represents a corporeal barrier between Askar and Misra. Askar is detached and weaned from his mother-figure Misra "for in the process of looking for a substitute, he had found another-Somalia, his mother country" (Farah, 1999, p. 100). In this stage, Askar is entrapped within the borders drawn on maps, not being aware that even maps can be "susceptible to distortion through political and military maneuver" (Ngaboh-Smart, 2001, p. 96). The third stage includes Askar's journey to Mogadiscio. Askar's uncle, Hilal, refers to the fact that Ethiopia, "because of its mélange of tribes, is generic, whereas Somalia, because of its unique possession of a common language, is specific." For Askar, this argument "undermines the Somali claim to uniqueness" (Ngaboh-Smart, 2001, p. 95). Askar becomes aware of the structured nature of borders. Askar's final adoption of a multicultural identity can be seen in the words of Hugo of St. Victor who says that the man who finds his homeland sweet is still a tender beginner, but he is perfect to whom the entire world is a foreign land (as cited in Said, 2000, p. 185). Askar comes to learn in the course of the events how "perfect" one can be by transcending national borders.

In the first stage, Askar is emotionally and physically enthralled by Misra. Askar remembers how Misra used to keep him warm by tucking him into the oozy warmth between her breasts, as if he were a third breast and how she would roll over on her back, so he would find himself between her open legs as if he were a third leg (p. 24). He admits that he is "a mere extension of Misra's body for years-you saw me when you set your eyes on her. I was part of the shadow she cast-in a sense, I was her extended self. I was, you might even say, the space surrounding the geography of her body" (p. 78). He recalls how Misra smelled of his urine the same way he smelled of her sweat (p. 10). For Askar, Misra was the one who took him back to the world of the womb and of innocence (p. 6), and the one on whose body of ideas his mind grew and nourished (p. 11). "Always . . . maternal, just like the cosmos, giving and giving," Misra tells Askar that he is "a blind man" and that she is his "stick" (p. 16). Expressing this unique relationship with his foster mother, Askar argues that Misra 
was the one that took you away from "yourself', as it were, she was the one who took you back into the world-of-the-womb and of innocence, and washed you clean in the water of a new life and a new christening, to produce in you the correct etches [sic] of a young self, with no pained memories, replacing your missing parents with the abundant self which she offered generously to you-her newly rediscovered child! (p. 6)

Misra gives Askar his identity. Moreover, there exists a specific thread that relates the construction of sexual identity to that of the national identity. We encounter the "misgendered" Askar. Askar mentions how Misra saw in him "a pretty princess surrounded with servants and wellwishers, one who could have anything she pleased and who was loved by her mother, but not much by her father because she was a girl and wouldn't inherit his title- wouldn't continue his line" (p. 7). The statement refers to Misra herself who was abandoned by her father because of her gender (p. 72). This means that Misra identifies her own female self with Askar whom she loved and pampered as a way of making up for the patriarchal cruelty she suffered when she was young. Indeed, Askar says, "I was once a young man-but I lost my identity" (p. 63). Throughout his life, Askar declares, "I have a strange feeling that there is another in me, one older than I-a woman" (p. 158). This woman later appears in Askar's dreams; she is "without a name, without a country, without parents" (p. 135). When Askar follows this woman, she declares that her name is "Askar Cali-Xamari" (p. 259).

Furthermore, after the Somali mingis ceremony where groups who are possessed by evil spirits gently pacify them, the woman reappears in Askar's dream as if it is the female within Askar that is released and soothed. In this dream, Askar was "moving upwards, inside [her] and he was traveling northerly, bearing slightly to the east, that is toward the sun, towards the ocean; and he cut comers, took short cuts, as he crawled towards the cavity from which emanated a voice, a human voice-his own." Describing Askar's journey towards wholeness, the woman exposes 
herself in a "fetal position" aspiring "to be born whole [and] to burst forth and be" (p. 191).

However, let us take a few more steps in the female world of Misra. This world has two main characteristics: The first is that it is neither ethnic nor claims a specific identity. In other words, Misra does not represent an Ethiopian figure; instead, she represents a multicultural figure: "[Misra] is, after all an Amharic speaking Oromo, not a full-blooded Ethiopian ... [she] is not a unitary being who can be comprehensively enclosed and defined by maps but represents the various parts of cultures and countriesOromo, Ethiopian, Somali-which are to be found in mongrelized migratory areas like the Ogaden." Misra's name manages to symbolize her multi-cultural identity: it exists in various languages, and its Somali form is an incomplete version of the Ethiopian "Misrat," meaning "foundation of the earth" and referring as it does to the unmapped earth (Wright, 1992, p. 180).

The second characteristic of the female world of Misra as a Somalian woman is that it is colonized and continuously abused by patriarchal authority, and since patriarchal authority is no more than a form of tyranny, then this patriarchal world is no more than a symbol for nationalist totalitarian political world that tries to subjugate the multicultural female world of Misra. Indeed, this parallelism between patriarchal authority and political authority is evident throughout the whole novel in the different male-female relationships. The Somali woman, as depicted by Farah, is repressed in her father's or husband's house. She is not only forced into marriage but also forced to endure polygamy and violence. Her role is restricted to sexual intercourses, giving birth, and raising children. One example is the relationship between Qorrax and Shahrawello. Qorrax beats his several wives (p. 13) yet is not condemned by society because beating women is acceptable in the Somali culture. Moreover, as soon as the Ogaden war is about to be won by Ethiopia, Qorrax becomes a traitor and works for the Ethiopian troops. Qorrax's brutality and selfishness are too much for her to tolerate. As a result of personal suffering and public shame, Shahrawello commits 
suicide. As Askar puts it, Quorrax "has made everyone ... suffer when he himself does not know what the word 'suffer' means. It is a tragedy" (p. 148).

On the other hand, Salaado's relationship with Hilaal is different and unusual. Hilaal is a feminist, and he cooks in his house instead of his wife. Salaado's frequent abortions did not matter for Hilaal despite his family's pressures on him to marry another woman. When Salaado had to remove her ovaries, Hilaal, out of compassion, undergoes a vasectomy. He triumphantly says, "She cannot have children, nor can I" (p. 150). Such equality in a husband and a wife's relationship is not accepted by society:

It's not all that simple, to be truthful. Society doesn't approve of a man who loves a woman who doesn't bear him children, a woman who doesn't cook his food, mind his home, wash his underthings. A woman who sits behind the wheel of a car driving when the man is a passenger- -to our society, this is unpardonable. It is sex, sooner or later. And there are the hierarchies which escort the notion of sex. (p. 151)

The female world of Misra is tainted by a coercive patriarchal authority. Misra was not only abandoned by her birth father because she is a girl, but she was also raped by her wealthy adoptive father. Upon murdering him, Misra becomes a mistress for another wealthy man who abandons her with a child who dies soon after. Furthermore, in order to be able to adopt Askar, Misra should gain the support of Qorrax. Qorrax is kind to her and allows her to adopt the child. However, "it was one thing to make a political (that is public) statement by being kind to her [but] it was another to give something for nothing" (p. 29). Despite repulsed by Qorrax, Misra sacrificed herself for the sake of Askar. Later on, Misra is raped by members in the national Liberation front who sees her as "a diseased part of the Somali heritage" (Wright, 1992, p. 179). This patriarchal authority, Farah believes, is a "microcosmic model" of dictatorship; for, according to Farah, a free country is unlikely until gender relationships and the negative image of women change (Sugnet,1998,p. 740). 
Now we come to the second stage in Askar's development in which Askar's internal conflict is emphasized. According to Wright (1990), Askar is torn between "sexual, national, and ontological boundaries ... in such a way as to dissolve the distinctions between the things they divide" (p. 27). Askar expresses his identity crisis when he contemplates,

You began debating with the egos of which you were compounded,and,detaching itself from the other selves, there stood before you, substantial as a shadow, the self which did not at all approve of your talking with or touching Misra, lest you were lost in the intensity of her embrace. For a long time, your selves argued with one another, each offering counter- arguments to the suggestions already submitted by the others. (p. 60)

The world of manhood is the world of barriers and borders. Within this second stage, there are three different barriers between Askar and Misra: a linguistic barrier, a corporeal barrier, and an intellectual barrier. If we agree that Askar's identity in the first stage can be viewed in the light of Lacan's "mirror stage," then it follows that the second stage initiates Askar in the symbolic order. In the first stage and according to Samuel Weber (1991), the sight of another human being becomes the matrix of the child's sense of identity (p. 12). Indeed, in Maps, mirrors are constantly there. Just after Misra's death, Askar "was standing before a mirror. He saw an unhappy face" (p. 255). How is Askar initiated in the world of the symbolic order? Askar is initiated into this world through "the acquisition of the Word, and even more importantly in Muslim culture, [this] initiation into the language of Allah entails a separation from the world of women" (Kazan, 1993, p. 260). Askar describes the first time when he was sent to the Koranic school as "the first painful separation" (p. 79). Moreover, the world of the symbolic order of manhood is the world of violence: uncle Qorrax tells Aw-Adan that Askar's flesh is his and that he may punish it to the extent of letting a bit of blood (p. 85); Aw-Adan beats Askar until he made a pool of bee (p. 79).

However, Askar does not shun the Word because of the violence that escorts it; what happens is the opposite: Askar clings to the Word which constitutes the first barrier between him and Misra: the Word, he 
thought, gives him the warmth and continuity he needed. Askar, as if to emancipate his body from being a shadow to Misra, would copy on his body verses of Kuran, until his veins flowed like ink, with the blood of the Word. The Word, he says, became the needed extension of his body ( $p$. 90) just as he, before, was the extension of Misra's (p. 78). In order to understand the paradox of Askar's clinging to the Word, though it separates him from his beloved foster mother, we should complete Weber's definition of Lacan's mirror stage. Weber (1991), after explaining how the child depends on the Other for the configuration of its identity, goes on to say how the "mirror" stage offers "the armor of an alienating identity, which will mark with its rigid structure the subject's entire mental life" (p. 4). This means a kind of conflict that inhabits Askar in his second stage: a conflict between clinging to the act of mapping his body violently with verses of Kuran (and later on with Somalia's map) and between going back to the female world of the womb and nurture. Misra attempts to cure Askar's tormented wavering spirit. When he returns from the Koranic school, Misra washes away the writings on his hands. Askar for a moment is possessed by the maternal affection of Misra: "I felt her calloused palms on my young, smooth skin, and felt ticklish and laughed and laughed and laughed and was very, very happy as only children can be"(p. 91). Despite such momentary fragility, Askar continues to move away from the world of Misra.

Later on, in Mogadiscio, the linguistic barrier will take more profound significance. Askar will mention how the Somali Orthography makes a wall of separation between him and Misra (p. 18). Furthermore, we are introduced to the oral tradition of the female world of Misra vis-à-vis the written tradition of the nationalist world hailed by Hilal: "To enter literacy is a proclamation of a new kind of power, one that differs from the immense power of the oral tradition to which he belongs, and Askar, whose name means 'bearer of arms,' has no doubt of the power of writing" (Kazan, 1993, p. 260). Indeed, Askar refers to this power: "every letter became a sword-by pronouncing it, I sharpened it; by drawing gave it a life of its own; all I had to do was to say 'Cut' and it would cut the enemy's head" (p. 176). Hilal tells Askar how history has proven that 
whoever is supported by the written metaphysics of tradition wins the fight to power; after this Askar sees every type of education as a nationalist plan (Ngaboh-Smart, 2001, p. 91).

Now we come to the corporeal barrier between Askar and Misra: Askar's circumcision. In her essay "Bleeding for the mother (land): Reading testimonial bodies in Nuruddin Farah's Maps," Michelle Lynn Brown (2010) asserts that Maps "represents traumatic suffering in images of bodily illness and mutilation to signify hypochondriacal responses to the psychic violence that accompanies the physical violation wrought by neocolonialism" (p. 125). Indeed, Askar wonders whether, after he becomes a man, he would remain an extension of Misra's physicality, as her third leg or third breast (p. 79). After being circumcised, Askar feels as if he is divided into two persons: one painless person who belongs to Misra and another injured person who is detached from her (p. 94). Askar describes this pain in one of the most touching statements in the novel:

It is such a horrid territory, the territory of pain. And I crossed it alone-no thought of Misra, no amount of consolatory remarks made by the uncle who had come with me and no verse of the Koran could've reduced the pain or even eliminated it altogether . . . I recall thinking that I had seen the bird's apparition and that the rest of the world had been small as a speck in the sky-then the man pulled at the foreskin of my manhood, producing, first in my groin, then in the remaining parts of my body, a pain so acute my ears were set ablaze with dolorous flames. (pp. 92-93)

Not strangely, then, that it is through Askar's convalescence that he got his first maps. Askar's use of maps occurs at a time when he began to identify with Somalia as a unified whole during the time of war (NgabohSmart, 2001, pp. 94-95). Askar, "using his own body ... redrew the map of Somali-speaking territories, copied it curve by curve, depression by depression" (pp. 101-102). Askar became convinced that he was, at last, a man, totally detached and weaned from his mother-figure Misra; for in the process of looking for a substitute, he had found another, Somalia, his mother country (p. 100). Indeed, Somalia is "[a] generous mother, a many-breasted mother, a many-nippled mother, a mother who gave 
plenty of herself and demanded loyalty of one, loyalty to an ideal, allegiance to an idea, the notion of a nationhood-no more, and no less" (p. 100).

Askar's identification of Somalia that takes place as a result of his ritual entrance to the world of manhood draws on the third barrier between him and Misra: an intellectual one. Askar's identification with Somalia resulted in his identification with his own community against Misra. Misra has already told Askar, "One day . . . you will identify yourself with your people and identify me out of your community. Who knows, you might even kill me to make your people's dream become a tangible reality" ( $p$. 99). After Askar's circumcision and his identification with the nationalistic paradigm of barriers and maps, Askar began to merge into his society: "In a month or so, especially now that his manhood was ringed with a healed circle, the orgies of self-questioning which were his wont, gave away to a state in which he identified himself with the community at large" (p. 100). This community is a part of the nationalistic specific paradigm that rejects the multicultural identity symbolized by Misra: Askar remembers how, after a few days of the outbreak of war, a mood of hostility prevailed against Misra and how his friends repeated their suspicions that she might be a traitor (p. 98). In other words, the nationalistic community into which Askar merges holds Misra intellectually in a distant arena because her ideas, as an Ethiopian, were assumed to be different.

So far, I have mentioned different barriers of the nationalistic world of manhood. Through all these barriers, Askar's construction of national identity is accompanied by a rising sense of manhood. At that time, that is, after Askar's initiation in the world of language, after his circumcision and after his identifying with Somalia and his community; at that time in which Askar's sense of manhood is so strong that-to emphasize it-he would hurt himself while shaving (p. 108) or vomit while eating (p. 109), at that time and in a kind of a magical realism incident: Askar menstruates. Askar's menstruation at this time specifically signifies a cry against the violence of the male world against all the barriers set between him and Misra by this world which he unconsciously rejects. Indeed, according to Wright (1990), Askar's menstruation-like blood is a metaphor 
"for the indiscriminate effects of the world, political and cosmic upon the human body" (p. 28). "Truth is body," (p. 236) Hilal would say, and Askar's menstruation is the truth proclaimed by his body, the body that longs to the warmth of Misra's body and their little world in which he was a princess and she was the cosmos. Without Misra, Askar argues, "It is as if I have no inside ... it feels as though I have no heart which beats, no lungs which breathe and no head which can think lucidly" (p. 127). Askar's weaning from Misra is traumatizing. This is why Askar tells Hilal that he has the strange feeling that there is another in him, one older than him, a woman. He describes how he feels that he is being spoken through as if he has allowed this woman to live inside him. Despite Askar's interpretation of this woman as his real mother, the fact is that this woman, a reality that Askar does not want to confess, is no more than Misra. Misra's figure is salient in Askar's many dreams: he dreams of a little girl following an old man as a goat follows a butcher (p. 4); he dreams of a young woman who was raped by her father (p. 62); he dreams of a woman calling him "my son" and talking about the pain of being separated from him (p. 110), all these figures represent Misra, the multicultural sense of identity who lives within Askar.

The third stage in Askar's development signifies the actual separation between Askar and Misra: Askar's journey to Mogadiscio. Ironically, when Askar's actual separation from Misra can be initially seen as one more barrier set between them, it is this journey that abolishes all the barriers mentioned above. When Askar travels to Mogadiscio, he experiences "the interilluminations of self and culture" which eventually calms his internal conflicts and spiritual pains (Ngaboh-Smart, 2001, p. 95). Once in Mogadiscio, Askar starts to reappraise his map. Askar's patriotic sentiments of Somali society are reformed by Hilal (Ngaboh-Smart, 2001, pp. 88-89). There is an argument made by Hilal and it is this argument that leads to Askar's realization of the inefficacy of borders and barriers: Hilal uses the expressive terms of "generic" and "specific":

In Hilal's use of these two designations, Ethiopia, because of its mélange of tribes is generic, whereas Somalia because of its unique possession of a common language, is specific. His argument ... [however] undermines the Somali claim to uniqueness ... From the 
argument, we learn that what defines a Somali refugee, for example, is not blood or lineage but political and economic necessity, and for Hilal to define Somalis now by language rings hollow (Ngaboh-Smart, 2001, p. 95).

Upon this conversation, Askar begins to move from the specific to the generic; he draws in his map, not the Ogaden, but simply Western Somalia. Askar begins to accept the fact that maps are liable to manipulation by political and military agendas (Ngaboh-Smart, 2001, p. 96).

Indeed, nationalism should be investigated within the context of the political regime which gives life to abstract nationalist slogans in order to perpetuate its existence. Askar starts to realize the constructed nature of borders. Robert Kaplan argues that "maps are a rebuke to the very notions of the equality and unity of humankind since they remind us of all the different environments of the earth that make men profoundly unequal and disunited in so many ways. (as cited in Patterson, 2014, p. 131) When Askar's passport photograph is taken from him he wonders if

it made any sense believing that passport size photographs would help anyone identify a person? Are we merely faces? I mean are faces the keys to our identity? What a man, like Aw-Adan, with a wooden leg- would you know it from the photograph? What a baby just born, a baby abandoned in a waste-bin, a baby, violent with betrayal- would you know its begetter, would you trace it to its mother or father? (p. 172 )

For Askar, maps are no more than an invented truth used as a tool of domination and hegemony. You can never judge a person according to his photograph, and you can never restrict one's hybrid identity within stabilized invented borders. Askar's former vision of nationalism as "paradisiacal tropicality" (p. 110) is replaced by an "infernally dark" nightmare of "paradisiacal disorder" (p. 121). According to Benedict Anderson (1991), the very notion of national identity is a part of "an imagined political community:"

Nationalism is not the awakening of nations to self-consciousness: it invents nations where they do not exist . . . so many millions of people [are willing], not so much to kill, as willingly to die for such 
limited imaginings ... These deaths bring us abruptly face to face with the central problem posed by nationalism: what makes the shrunken imaginings of these of recent history (scarcely more than two centuries) generate such colossal sacrifice? I believe that the beginnings of an answer lie in the cultural roots of nationalism. (p. 6-7)

Misra's Mastectomy reverberates Askar's circumcision. In both cases, psychological traumas are symbolized by physical amputations. According to Wright (1992), these amputations represent the "dismemberment and fragmentation of the Ogaden" (p. 177). Visiting her at the hospital, Askar sympathizes with Misra. Misra and Askar's conversation was "replete with empty silences, unfilled spaces, incomplete dots, and inconsistent holding on to, or letting go of, certain consonants" (p. 218). Nevertheless, Askar and Misra are unified once more through their shared pains. Askar is on the way to gain his independence, to soothe his tormented soul and to resolve the painful conflict that has been controlling him so far.

Nevertheless, why then does Askar dream of killing Misra? This dream can be explained in reference to Edward Said (2000) who sees nationalism "as an assertion of belonging in and to a place, a people, a heritage. It affirms the home created by a community of language, culture, and customs; and, by doing so, it fends off exile" (p. 176). Said argues, "And just beyond the frontier between 'us' and the 'outsider' is the perilous territory of not-belonging," and it is this territory that Askar fears. Said goes on to say that exiles prefer to see themselves "as a part of $a$ triumphant ideology" in order to make up for their lost land and past. Indeed, it is this triumphant nationalistic ideology to which Askar clings. Said asks: "what is there worth saving and holding on to between the extremes of exile on the one hand and the often bloody-minded affirmations of nationalism on the other?" (p. 177)

Maps answers this question by introducing the concept of multiculturalism in front of which the borders, even those of gender, dissolve. The very fact that Askar narrates Maps, the very fact that Askar, using the first, second, and third, person narratives thus affording the appropriate sincerity, and avoiding any partiality against Misra, means 
that after Misra's death, Askar comes to realize that he may not fall in the territory of not-belonging if he shuns the idealistic nationalistic male world. Instead, through accepting multiculturalism, he will be conscious of what Said (2000) calls, "contrapuntal juxtapositions that diminish orthodox judgments and elevate appreciative sympathy" (p. 186). Misra sacrificed her life for Askar, for it is through her death that Askar comes to find his pluralistic identity. Indeed, Misra's life was a life of "sacrifice": "He repeated the word to himself, like a blind man touching the items surrounding him, a man familiarizing the senses of his body with what his mind already knows. And he saw. He saw Misra divine" (p. 257). The divine woman living inside Askar is a symbol of a multicultural sense of identity; Askar comes to realize how borders and barriers which enclose one within the safety of familiar territory can also become prisons (Said, 2000, p. 185).

Anderson (1991) talks about "the near-pathological character of nationalism, its roots in fear and hatred of the Other, and its affinities with racism" (p. 141). Instead, Farah introduces the paradoxical concept of post-nationalism which deconstructs the "nationalists' obsessive concern with indigenous values as a mark of identity," (Ngaboh-Smart, 2001, p. 86) putting an emphasis instead on transnational, flexible and pluralistic identity. Indeed Farah's Maps trespasses all kinds of borders - be it social, gender, or geographical- showing the unstable nature of the notion of nationalism (Yaweh, 2001, p. 45). 


\section{Endnotes}

1-Farah's first novel, From a Crooked Rib (1970) is a feminist work in which Farah attacks the traditional role of women in his society. In his second novel, $A$ Naked Needle (1976), "Farah used a slight tale of interracial and cross-cultural love to reveal a lurid picture of postrevolutionary Somali life in the mid-1970s." Naked Needle would earn Farah a high reputation as a writer, yet he would be warned that the Somali government intends to arrest him because of the novel's contents. Accordingly, Farah decided to travel abroad and continue his noteworthy career as a writer and a lecturer. In exile, Farah would write his first trilogy Variations on the Theme of an African Dictatorship which includes Sweet and Sour Milk (1979), Sardines (1981), and Close Sesame (1983). Farah's second and most distinguished trilogy is 'Blood in the Sun' which consists of the novels Maps (1986), Gifts (1993), and Secrets (1998). His following Past Imperfect trilogy includes Links (2004), Knots (2007) and Crossbones (2011). Farah's most recent novels are Hiding in Plain Sight (2014) and North of Dawn (2018) (Encyclopedia Brittanica).

2-"The narrator, Azaro, is a spirit child who maintains his ties to the supernatural world. Possessed by "boiling hallucinations," he can see the invisible, grotesque demons and witches who prey on his family and neighbors in an African ghetto community. For him (and for the reader), the passage from the real to the fantastic world is seamless and constant; many of the characters--the political thugs, grasping landlords and brutal bosses--are as bizarre as the evil spirits who empower them. In a series of vignettes, Azaro chronicles the daily life of his small community: appalling hunger and squalor relieved by bloody riots and rowdy, drunken parties, inhuman working conditions, and rat-infested homes. The cyclical nature of history dooms human beings to walk the road of their lives fighting corruption and evil in each generation, fated to repeat the errors of the past without making the ultimate progress that will redeem the world" (Talese, 1992). 
3-"In 1977, Ethiopia and Somalia engaged in a brief territory conflict over the Ogaden region situated between and claimed by both nations. This conflict, however, held significance greater than most territorial disputes because Ethiopia was backed by the Soviet Union and Somalia was supported by the United States, thus bringing the Cold War to eastern Africa. Long before the 1977 conflict, the Ogaden had been subject to dispute. Following World War II, when Ethiopia had been aligned with the Allies against the Axis Powers, Great Britain relinquished its claim on the Haud and Ogaden regions as part of British-Somaliland. When British Somaliland became part of the newly independent nation of Somalia in 1960, the government took control over the region. They intensified their control when a military coup led to the assassination of Somali President Abdirashid Ali Shermarke, and the army's seizure of control of the nation in 1969" (Yared, 2016). 


\section{References}

Anderson, B. (1991). Imagined Communities: Reflections on the Originand Spread of Nationalism. London: Verso.

Barker,C.(2004). The Sage Dictionary of Cultural studies. London: SAGE Publications.

Brown,M.(2010). Bleeding for the Mother (Land):Reading Testimonial Bodies in Nuruddin

Farah's Maps. Research in African Literatures,41(4), 125-143.

https:// jstor.org/stable/10.2979/ral.2010.41.4.125.

Ephrem, Y. (2016, March 21). Ethiopian-Somali War Over the

Ogaden.. University of Washington Jorurnal. https://blackpast.org/global-african-history/ethiopiansomali-war-over-ogaden-region-1977-1978/.

Encyclopedia Brittanica. https://brittanica.com/biography/Nurruddin-Farah.

Farah, N. (1995). Bastards of Empire: Writing and the Politics of Exile. Transition, 65(1), 26.

---. (1996). Salvaging the Soul of a Nation, W. H.Gass and L. Cuoco (Eds.), The Writer in Politics. Carbondale, IL: Southern Illinois University Press.

---. (1998). A Country in Exile. Transition, 57(1), 4-8.

---. (1999). Maps. New York: Arcade Publishing.

Hall, S. (1992).Cultural Studies and its Theoretical Legacies, L.

Grossberg, C. Nelson and P. Treichler (Eds.), Cultural Studies. London and New York: Routledge. PP. 277-294.

Kazan, F. (1993 Spring). Recalling the Other Third World: Nuruddin Farah's Maps. Novel: A Forum on Fiction, 26(3), 253, 15.

Kellner, D. (2001). Cultural Studies and Social Theory: A Critical Intervention,1-23.

https://www.gseis.ucla.edu/faculty/kellner/

Ngaboh-Smart, F. (2001). Nationalism and the Aporia of National Identity in Farah's Maps. Research in African Literatures, 32(3).

Patterson, A. (2014). The International Novel. New Haven, CT: Yale University Press. 
Said, E. (2000). Reflections on Exile and Other Literary Cultural Essays. London: Harvard University Press.

Sugnet, Ch. (1998). Nuruddin Farah's Maps: Deterritorialization and The Postmodern. World Literature Today, 72(4), 739-46.

Talese, A. (1992, April 05). The Famished Road [ Review of the novel The Famished Road, by Ben Okri]. https://publishersweekly.com/978-0-385-42476-9.

Weber, S. (1991). Return to Freud (M, Levine, Trans.) Cambridge: Cambridge UP.

Wright, D. (1990). Zero Zones: Nuruddin Farah's Fiction. A Review of International English Literature, 21(2), 21-42.

---. (1992). Parenting the nation: Some observations on Nurrudin Farah's Maps. College Literature, 19/20(3/1), 176-184.

Yahweh, E. (2001). The Nation as a Contested Construct. Research in African Literatures, 32(3), 45-56. 